\title{
Both exogenous 5-HT and endogenous 5-HT, released by fluoxetine, enhance distension evoked propulsion in guinea-pig ileum in vitro
}

\author{
Rachel M. Gwynne ${ }^{1 *}$, Amanda J. Clarke ${ }^{1}$, John B. Furness ${ }^{2}$ and Joel C. Bornstein ${ }^{1}$ \\ ${ }^{1}$ Department of Physiology, University of Melbourne, Parkville, VIC, Australia \\ ${ }^{2}$ Departments of Anatomy and Cell Biology, University of Melbourne, Parkville, VIC, Australia
}

\section{Edited by:}

Jack Grider, Virginia Commonwealth

University, USA

\section{Reviewed by:}

Nicholas Spencer, Flinders

University, Australia

Xiaochun Bian, Michigan State

University, USA

\section{*Correspondence:}

Rachel M. Gwynne, Department of Physiology, University of Melbourne, Medical Building, Cnr Grattan St. and Royal Pde., Parkville, VIC 3010, Australia

e-mail: rgwynne@unimelb.edu.au
The roles of $5-\mathrm{HT}_{3}$ and $5-\mathrm{HT}_{4}$ receptors in the modulation of intestinal propulsion by luminal application of 5-HT and augmentation of endogenous 5-HT effects were studied in segments of guinea-pig ileum in vitro. Persistent propulsive contractions evoked by saline distension were examined using a modified Trendelenburg method. When 5-HT $(30 \mathrm{nM})$, fluoxetine (selective serotonin reuptake inhibitor; $1 \mathrm{nM}), 2$-methyl-5- $\mathrm{HT}\left(5-\mathrm{HT}_{3}\right.$ receptor agonist; $1 \mathrm{mM})$, or RS $67506\left(5-\mathrm{HT}_{4}\right.$ receptor agonist, $\left.1 \mu \mathrm{M}\right)$ was infused into the lumen, the pressure needed to initiate persistent propulsive activity fell significantly. A specific 5- $\mathrm{HT}_{4}$ receptor antagonist, SB 207266 (10 nM in lumen), abolished the effects of 5-HT, fluoxetine, and RS 67506, but not those of 2-methyl-5-HT. Granisetron $\left(5-\mathrm{HT}_{3}\right.$ receptor antagonist; $1 \mu \mathrm{M}$ in lumen) abolished the effect of $5-\mathrm{HT}$, fluoxetine, RS 67506, and 2-methyl-5-HT. The NK 3 receptor antagonist SR 142801 (100 nM in lumen) blocked the effects of 5-HT, fluoxetine, and 2-methyl-5-HT. SB 207266, granisetron, and SR 142801 had no effect by themselves. Higher concentrations of fluoxetine (100 and $300 \mathrm{nM})$ and RS $67506(3$ and $10 \mu \mathrm{M})$ had no effect on the distension threshold for propulsive contractions. These results indicate that luminal application of exogenous 5-HT, or increased release of endogenous mucosal 5-HT above basal levels, acts to lower the threshold for propulsive contractions in the guinea-pig ileum via activation of $5-\mathrm{HT}_{3}$ and $5-\mathrm{HT}_{4}$ receptors and the release of tachykinins. The results further indicate that basal release of 5-HT is insufficient to alter the threshold for propulsive motor activity.

Keywords: serotonin, $5-\mathrm{HT}_{3}$ receptors, $5-\mathrm{HT}_{4}$ receptors, $\mathrm{NK}_{3}$ tachykinin receptors, intestinal motility

\section{INTRODUCTION}

The intestinal mucosa is the major site of synthesis of serotonin (5-HT) in the body, but the role of mucosal 5-HT in controlling intestinal motility remains controversial. Gastric emptying, jejunal transit and transit through the entire gastrointestinal tract in vivo are normal in mice lacking tryptophan hydroxylase 1, the rate limiting enzyme for 5-HT synthesis in enterochromaffin (EC) cells (Li et al., 2011). However, in vitro analysis of propulsive motility in the colon from the same mice indicates that 5-HT released by EC cells facilitates normal propulsion; in knock out animals, reflex responses to distension were reduced and only larger fecal pellets were propelled (Heredia et al., 2013). These studies are consistent with other studies showing that complete removal of the mucosa and blockade of mucosal 5-HT release does not prevent initiation of colonic propulsion (Spencer et al., 2011), colonic contractile complexes (Keating and Spencer, 2010) or polarized reflex responses of the muscle (Costa and Furness, 1976). This may reflect the finding that distension does not produce 5-HT release from the colonic mucosa (Grider et al., 1996). However, luminal application of 5-HT antagonists can slow, but not prevent, propulsion in guinea-pig colon (Jin et al., 1999). Thus, it appears that colonic propulsion does not require mucosal 5-HT, but may be enhanced when mucosal $5-\mathrm{HT}$ is released.

A similar picture is seen in the small intestine where mucosal 5-HT does not initiate propulsive motor activity evoked by distension, but may facilitate this activity (Tuladhar et al., 1997). Moreover, the mechanisms by which mucosally released 5-HT activates different motor patterns in the small intestine of the guinea-pig appear to be complex. Mucosal 5-HT plays a key role in nutrient (decanoic acid) induced segmentation in guinea-pig small intestine as blocking either $5-\mathrm{HT}_{3}$ or $5-\mathrm{HT}_{4}$ receptors, at the level of the mucosa, virtually abolishes this motor pattern (Ellis et al., 2013). However, while luminal decanoic acid causes an increase in both segmenting and propulsive motor activity, luminal fluoxetine $(100-300 \mathrm{nM})$ which releases mucosal 5-HT only triggers segmenting activity, again via $5-\mathrm{HT}_{3}$ and $5-\mathrm{HT}_{4}$ receptors (Ellis et al., 2013). On the other hand, cholera toxin, which would be expected to release mucosal 5-HT, increases propulsive motor activity at resting intraluminal pressures and enhances propulsive motor patterns evoked by distension, each via mechanism(s) independent of 5- $\mathrm{HT}_{3}$ receptors (Fung et al., 2010).

It has been reported that propulsive motor activity evoked by saline distension is enhanced by luminal $5-\mathrm{HT}$ via $5-\mathrm{HT}_{3}$ 
receptors close to, if not in, the mucosal epithelium and that $5-\mathrm{HT}_{4}$ receptors are not required (Tuladhar et al., 1997). In contrast, local inhibitory reflexes evoked by amino acids transiently applied to the mucosa are depressed by blockade of both $5-\mathrm{HT}_{3}$ and $5-\mathrm{HT}_{4}$ receptors, but not blockade of either subtype on its own (Gwynne and Bornstein, 2007). Furthermore, 5-HT applied via the serosa can enhance saline evoked propulsive motor patterns via $5-\mathrm{HT}_{4}$ receptors, while $\mathrm{EC}$ cells have been shown to express $5-\mathrm{HT}_{4}$ receptors (Hoffman et al., 2012). Whether $5-\mathrm{HT}_{3}$ and $5-\mathrm{HT}_{4}$ mediated effects of exogenous 5-HT are independent of each other or are part of the same pathway is unclear, as is their relevance to the roles of endogenous 5-HT. This study was designed to address these issues.

Electrophysiological studies of guinea-pig ileum indicate that 5-HT applied to the mucosa excites the mucosal terminals of $\mathrm{AH}$ neurons with cell bodies in the myenteric plexus via $5-\mathrm{HT}_{3}$ receptors (Bertrand et al., 1997, 2000; Bertrand and Bornstein, 2002). Mucosally applied 5-HT also evokes slow excitatory synaptic potentials (EPSPs) in myenteric AH neurons (Bertrand et al., 1997, 2000) presumably via synapses from directly activated $\mathrm{AH}$ neurons. These slow EPSPs would be expected to increase the firing of distension-sensitive $\mathrm{AH}$ neurons, thus enhancing reflexes evoked by distension. Most slow EPSPs in myenteric AH neurons are blocked by the specific $\mathrm{NK}_{3}$ tachykinin receptor antagonist SR 142801 (Alex et al., 2001; Johnson and Bornstein, 2004) which suggests that luminally applied 5-HT may facilitate propulsive reflexes in the guinea-pig ileum via the release of a tachykinin. Accordingly, we also investigated this possibility.

Propulsive motor activity was studied using a modified Trendelenberg preparation in which the stimulus was a saline distension; agonists and antagonists were added to the luminal perfusion solution. The concentration of 5-HT used was $30 \mathrm{nM}$ as preliminary experiments indicated that this was sufficient to facilitate propulsive reflexes. The time of exposure was over $1 \mathrm{~h}$ to mimic the effects of a nutrient stimulus that might release 5-HT (Gwynne et al., 2004; Ellis et al., 2013). The effects of exogenous 5-HT were compared with those of endogenous 5-HT whose effects were revealed by a selective serotonin reuptake inhibitor, fluoxetine.

\section{MATERIALS AND METHODS TISSUE PREPARATION}

Guinea-pigs (150-350g) of either sex were killed by being stunned and having their carotid arteries severed. This procedure was approved by the University of Melbourne Animal Experimentation Ethics Committee. The composition (in $\mathrm{mM}$ ) of physiological saline used in all experiments was: $\mathrm{NaCl} 118$, $\mathrm{KCl} 4.8, \mathrm{NaH}_{2} \mathrm{PO}_{4}$ 1, $\mathrm{NaHCO}_{3} 25, \mathrm{MgSO}_{4}$ 1.2, d-glucose 11, $\mathrm{CaCl}_{2} 2.5$, bubbled with $95 \% \mathrm{O}_{2}, 5 \% \mathrm{CO}_{2}$. Segments of ileum $8-10 \mathrm{~cm}$ in length, were taken $10-20 \mathrm{~cm}$ proximal to the ileocaecal junction, flushed clean, cannulated, and placed in an organ bath containing physiological saline at $37^{\circ} \mathrm{C}$. Intraluminal pressure was measured via a $\mathrm{T}$-piece connected to the anal cannula and recorded using a BIOPAC Systems MP100 recording unit and Acknowledge v. 3.25 software (SDR Clinical technology, NSW). In some experiments, video images of the intestinal segment were recorded and later processed using edge-detection software to produce spatio-temporal maps. These methods have previously been described in Gwynne et al. (2004) and confirmed that the recorded pressure increases corresponded to a propulsive motor pattern.

\section{EXPERIMENTAL PROTOCOLS}

Once the ileal segments had been dissected and cannulated, $10 \mathrm{~mL}$ of the physiological saline was flushed through the lumen and the preparation left to equilibrate for $1 \mathrm{~h}$. During the equilibration period, the height of the saline in the reservoir was level with the segment of ileum, so the inflow pressure head was held to zero, below the threshold for initiation of propulsive contractions. Following equilibration, the pressure threshold for initiation of persistent propulsive contractions (measured as repeated transient increases in intraluminal pressure, see Gwynne et al., 2004 for definition) was determined by raising the inflow pressure in steps of $1 \mathrm{~cm} \mathrm{H}_{2} \mathrm{O}$ at intervals of approximately $30 \mathrm{~s}$, until this motor pattern was initiated. The inflow pressure was then returned to control levels. The pressure which triggered the persistent propulsive contractions was consistent for several hours in any one preparation and was taken as the threshold for propulsive motor activity (or peristalsis) (Gwynne et al., 2004). After each trial, the height of the inflow reservoir was returned to the starting level and the preparation was allowed to rest for $10 \mathrm{~min}$. After 3-4 control measurements, an agonist (or fluoxetine) was added to the inflow reservoir and the drug was flushed into the lumen. The preparation was allowed to equilibrate for $1 \mathrm{~h}$ before a second set of 3 threshold measurements was recorded. When the effects of antagonists were studied after the initial exposure to an agonist, approximately $30 \mathrm{~mL}$ of fresh saline was flushed through the lumen and left to equilibrate for $20 \mathrm{~min}$ before a combination of agonist and antagonist was applied luminally. After a further $1 \mathrm{~h}$ equilibration period, a final set of 3 threshold measurements was made. Each antagonist was also tested by itself using the protocol for agonists. Where video recordings were made, images were acquired at a frame rate of 10 frames per second for the duration of the threshold measurement.

Data in the text is given as mean \pm s.e.m. except where otherwise stated.

Statistical comparisons were made using paired $t$-tests or One Way analysis of variance (ANOVA); $P$-values $<0.05$ were considered significant.

\section{DRUGS}

Drugs used were 5-HT, fluoxetine, 2-methyl-5-hydroxytryptamine (2-me-5-HT) (all from Sigma Aldrich, NSW), RS 67506 (Tocris Cookson Ltd. Bristol, UK), tetrodotoxin (Alomone Labs Ltd. Jerusalem, Israel), granisetron, SB 207266 (both supplied by Glaxo SmithKline, Harlow, UK), and SR 142801 (supplied courtesy of Dr. X. Emonds-Alt, Sanofi Recherche, France). All were initially made up in distilled water to make stock solutions. To avoid oxidation, new 5-HT solutions were made up each week.

\section{RESULTS}

Figure 1 shows an example of the propulsive contractions evoked by increasing the intraluminal pressure to threshold. Step-wise 


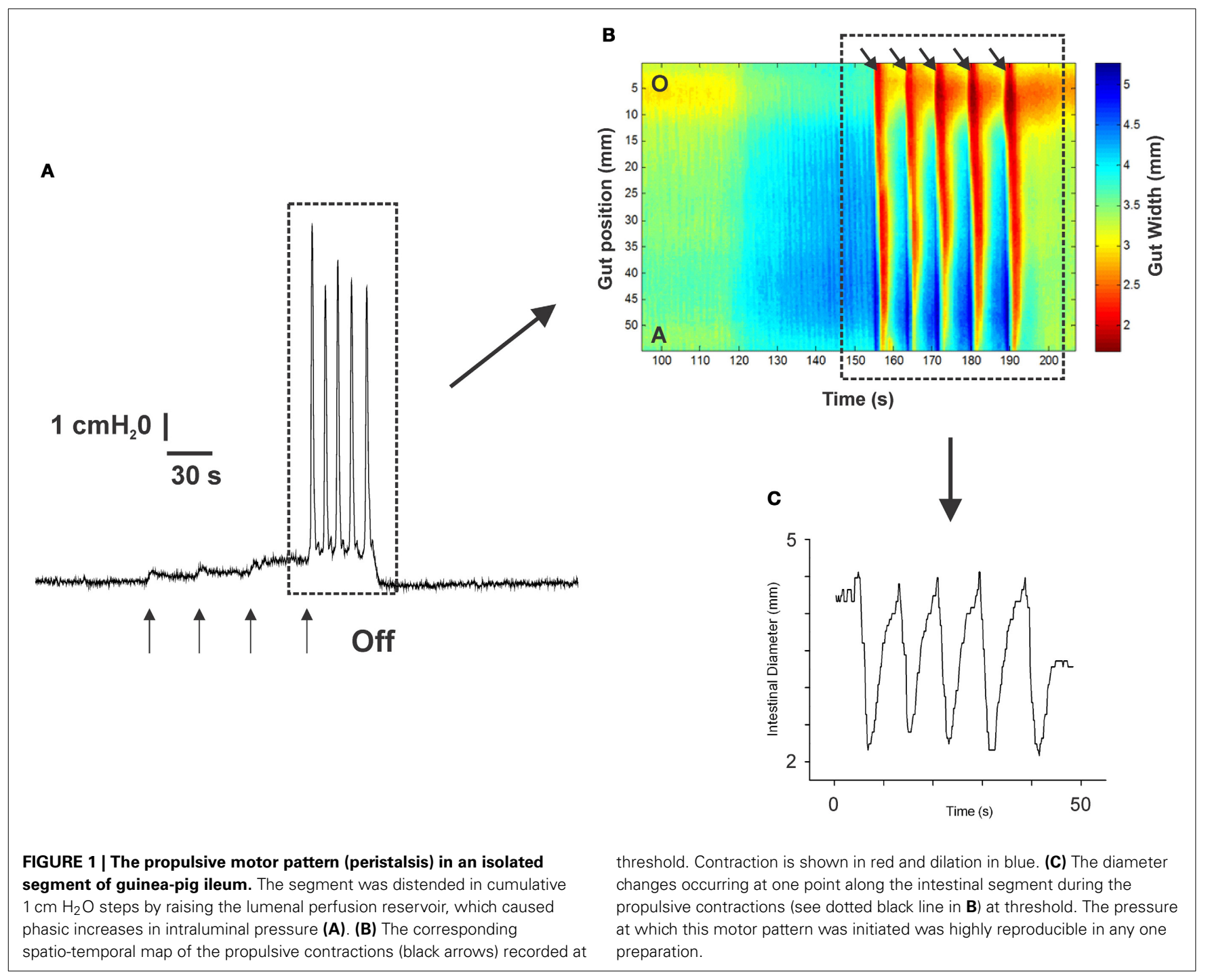

increases in intraluminal pressure to levels below the threshold for persistent propulsive contractions sometimes evoked one or more propagating contractions of the circular muscle (not shown here). We have previously described these as "transient propulsive contractions" (Gwynne et al., 2004). Threshold pressures that evoked consistent propulsive contractions ranged from 4 to $8 \mathrm{~cm}$ $\mathrm{H}_{2} \mathrm{O}$ (median $6.5 \mathrm{~cm} \mathrm{H}_{2} \mathrm{O}$ ) in 102 preparations. When the threshold was reached, the propulsive contractions were regular and persisted throughout the period of increased luminal pressure, ceasing immediately the pressure was reduced below the threshold (Figure 1). Luminal 5-HT (30 nM) and luminal fluoxetine (1 nM) reduced the threshold for the persistent propulsive contractions by 25 and $40 \%$, respectively (Figures 2A,B; $5-\mathrm{HT}-P<0.01$, $n=6$, fluoxetine $-P<0.001, n=6$ ). In each case, the effects reversed on washout of the agonist. The changes in threshold were accompanied by a statistically significant increase in the rate of propagation of the propulsive contractions measured via spatiotemporal maps (control $21.6 \pm 1.1 \mathrm{~mm} / \mathrm{s}, 5-\mathrm{HT} 30.4 \pm$ $1.4 \mathrm{~mm} / \mathrm{s}, n=6, P<0.001$; control $14.5 \pm 1.0 \mathrm{~mm} / \mathrm{s}$, fluoxetine $20.2 \pm 1.3 \mathrm{~mm} / \mathrm{s}, n=4, P<0.01)$ and a significant reduction

in the diameter of the ileum at the threshold pressure (control $3.2 \pm 0.02 \mathrm{~mm}, 5$-HT $2.8 \pm 0.01 \mathrm{~mm}, P<0.05, n=4$; control $3.0 \pm 0.02 \mathrm{~mm}$, fluoxetine $2.4 \pm 0.01 \mathrm{~mm}, P<0.05, n=4)$.

Higher concentrations of fluoxetine $(100$ and $300 \mathrm{nM})$ in the lumen had no significant effect on the threshold pressure for the persistent propulsive contractions (control $4.8 \pm 0.1100 \mathrm{nM}$ fluoxetine $4.8 \pm 0.1 \mathrm{~cm} \mathrm{H}_{2} \mathrm{O}$; control $4.6 \pm 0.1,300 \mathrm{nM}$ fluoxetine $4.7 \pm 0.1 \mathrm{~cm} \mathrm{H}_{2} \mathrm{O}$ ) although they did produce an increase in contractile activity at basal pressures. The effects of luminal 5-HT were mimicked by the specific $5-\mathrm{HT}_{3}$ receptor agonist 2-me-5-HT ( $1 \mathrm{mM}, n=6)$, and by a specific $5-\mathrm{HT}_{4}$ receptor agonist $\mathrm{RS} 67506$ $(1 \mu \mathrm{M}, n=6)$, which reduced the pressure threshold for propulsive contractions by $35 \%(P<0.0001)$ and $12 \%(P<0.01)$, respectively (Figures 2C,D). As with fluoxetine, higher concentrations of RS $67506(3$ or $10 \mu \mathrm{M})$ produced no apparent change in threshold for activation of persistent propulsive contractions, but increased the overall contractile activity at basal pressures. In each case, the increased contractile activity at basal pressures involved predominantly segmenting contractions (see Figure 1 of Ellis et al., 2013). 
(I) SB $20726610 \mathrm{nM}$

A 5-HT (30nM)

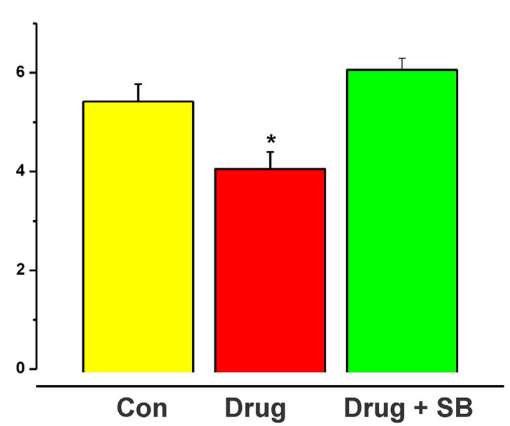

B Fluoxetine (1 $\mathrm{nM}$ )
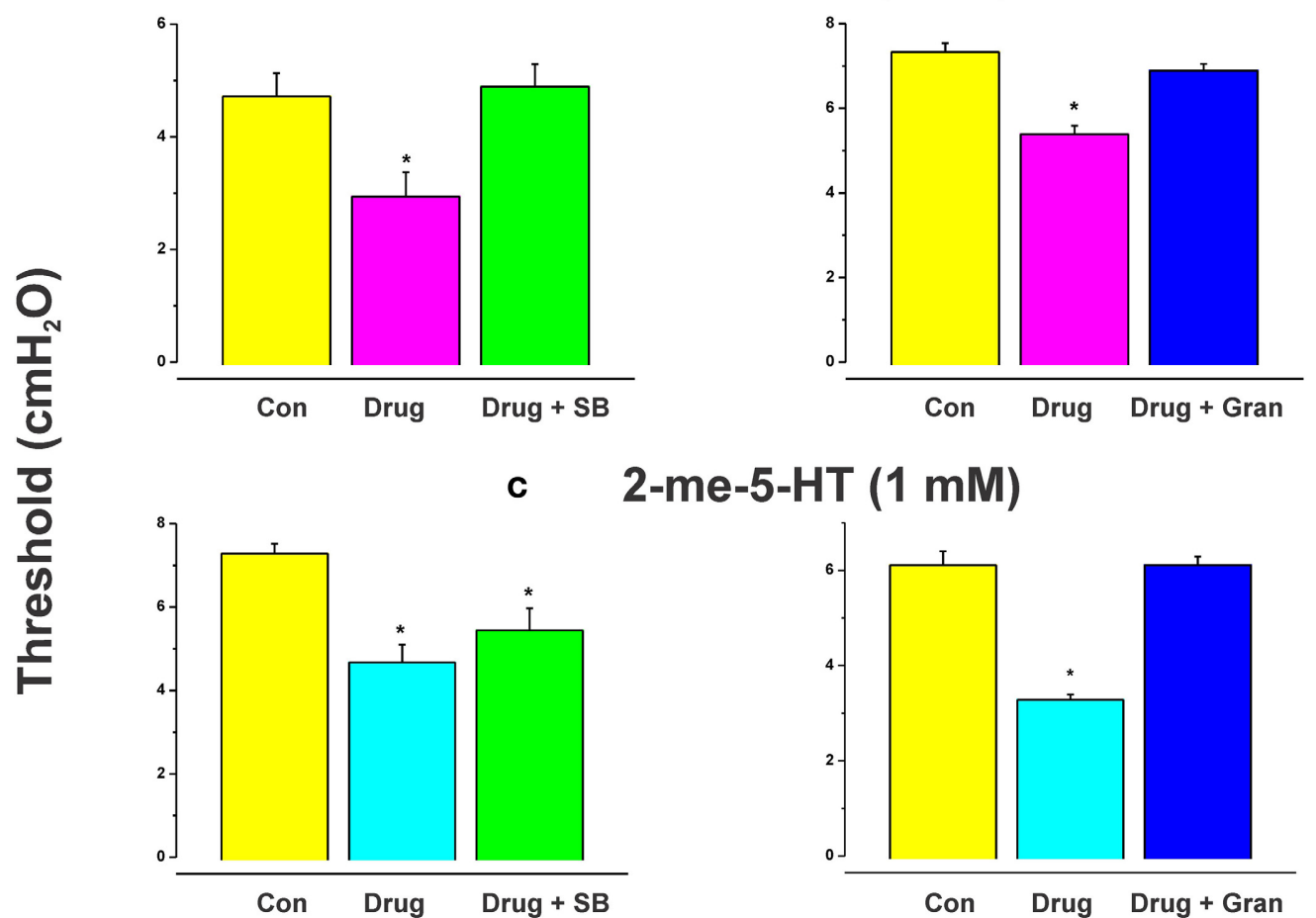

2-me-5-HT (1 mM)

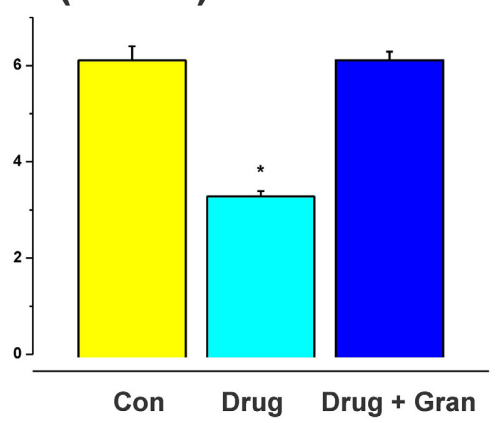

D $\quad$ RS $67506(1 \mu \mathrm{M})$
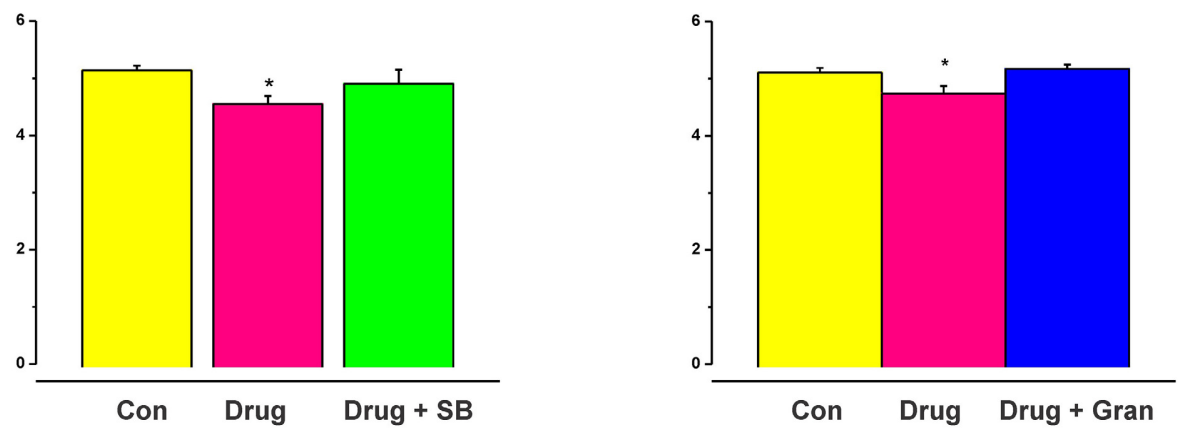

(II) Granisetron $1 \mu \mathrm{M}$

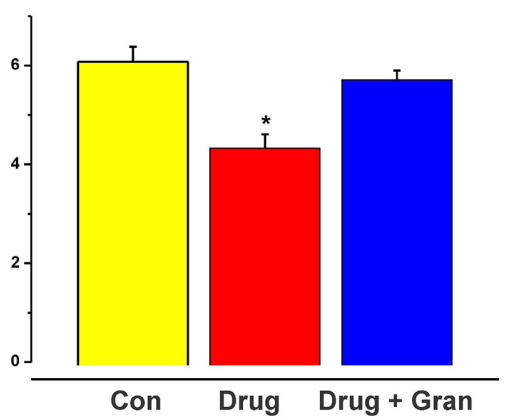

Drug + Gran
FIGURE 2 | Effects of exogenous 5-HT, endogenous 5-HT potentiated by fluoxetine, 2-me-5-HT, and RS 67506 on the threshold pressure for initiation of propulsive contractions. Histograms showing the mean ( \pm s.e.m.) thresholds in $\mathrm{cm} \mathrm{H}_{2} \mathrm{O}$ for initiation of peristalsis in control, with the 


\section{FIGURE 2 | Continued}

to the lumen. The reduction in threshold was significant in each case [(A) 5-HT, $P<0.01$; (B) fluoxetine, $P<0.01,2-$ me-5-HT, $P<0.0001$, RS 67506, $P<0.01]$. The histograms in the left column show the effects of the $5-\mathrm{HT}_{4}$ receptor antagonist SB $207266(10 \mathrm{nM})$ in the lumenal perfusate on the changes in threshold for initiation of propulsive motor patterns in the ileum induced by 5-HT (A), fluoxetine (B), 2-me-5-HT (C), or RS 67506 (D). The right column shows the effects of the $5-\mathrm{HT}_{3}$ receptor antagonist granisetron $(1 \mu \mathrm{M})$ on the changes induced by the same compounds. SB 207266 blocked the facilitation caused by luminal 5-HT, fluoxetine, and RS 67506 [panels $\mathbf{A}(\mathbf{I}), \mathbf{B}(\mathbf{I}), \mathbf{D}(\mathbf{I})]$ but did not abolish the effects of 2-me-5-HT [panel $\mathbf{C}(\mathbf{I})]$. In contrast, granisetron blocked the facilitation of peristalsis produced by all of the agonists tested $[\mathbf{A}(\mathbf{I I}), \mathbf{B}(\mathbf{I I}), \mathbf{C}(\mathrm{II}), \mathbf{D}(\mathbf{I I})]$. * indicates significantly different from control with $P<0.05$ in all cases.
When added to the luminal perfusion solution, a highly specific 5- $\mathrm{HT}_{4}$ receptor antagonist SB $207266(10 \mathrm{nM})$ (Wardle et al., 1996) blocked the facilitation caused by luminal 5-HT, fluoxetine, and RS 67506 [Figures $2 \mathrm{~A}(\mathrm{I}), \mathbf{B}(\mathrm{I}), \mathbf{D}(\mathrm{I})$, all $n=6$ ] but did not alter the effects of 2-me-5-HT [Figure 2C(I), n=6]. In contrast, a specific $5-\mathrm{HT}_{3}$ receptor antagonist granisetron $(1 \mu \mathrm{M})$ (29) blocked the facilitation of persistent propulsive contractions produced by all agonists tested. (5-HT $n=8$, fluoxetine $n=6$, RS $67506 n=6$ and 2-me-5-HT $n=6$ ) [Figures 2A(II), B(II),C(II),D(II)].

SB $207266(10 \mathrm{nM})$ and granisetron $(1 \mu \mathrm{M})$ when added to the luminal perfusate on their own, or in combination, had no effect on the threshold pressure for initiation of persistent propulsive contractions (Figure 4, $n=6$ in each case).

\section{ROLE OF NK ${ }_{3}$ TACHYKININ RECEPTORS}

The effects of luminal 5-HT, fluoxetine, and 2-me-5HT were all prevented by simultaneous addition of the specific $\mathrm{NK}_{3}$ tachykinin receptor antagonist SR $142801(100 \mathrm{nM})$ to the luminal perfusate (Figure 3, each $n=6$, RS 67506 not tested). SR 142801 had no effect on the threshold pressure when added to the luminal perfusate on its own (Figure $4 \mathrm{D}, n=6$ ) or when added to the superfusing solution (not illustrated).

\section{DISCUSSION}

This study indicates that perfusion of exogenous 5-HT through the lumen, or increases in release of endogenous mucosal 5-HT above basal levels, facilitates intestinal propulsion evoked by saline distension of the ileum via activation of $5-\mathrm{HT}_{4}$ and $5-\mathrm{HT}_{3}$ receptors and the release of tachykinins acting at $\mathrm{NK}_{3}$ receptors. We found no evidence that basal release of mucosal 5-HT was sufficient to activate these receptors.

\section{SITE OF ACTION OF 5-HT}

Figure 5 illustrates the sites of action and locations of receptors that are deduced from this study. Facilitation of propulsion by 5 HT or fluoxetine was reversed by either the $5-\mathrm{HT}_{4}$ receptor antagonist, SB 207266 or the $5-\mathrm{HT}_{3}$ receptor antagonist, granisetron. Furthermore, luminal application of the specific $5-\mathrm{HT}_{3}$ receptor agonist 2-me-5-HT or $5-\mathrm{HT}_{4}$ receptor agonist RS $67506 \mathrm{mim}-$ icked the effects of 5-HT and fluoxetine. This indicates that the mechanism underlying the facilitation occurs via activation of both $5-\mathrm{HT}_{3}$ and $5-\mathrm{HT}_{4}$ receptors in this system. These data contrast with previous research by Tuladhar et al. (1997) who found that mucosally applied 5-HT facilitates propulsive reflexes via activation of $5-\mathrm{HT}_{3}$ receptors, but they found no evidence for $5-\mathrm{HT}_{4}$ receptor involvement. One reason for this difference is likely to be the marked differences in concentration of 5-HT used in the two studies. We observed facilitation with $30 \mathrm{nM} 5-\mathrm{HT}$, three orders of magnitude lower than the lowest effective concentration used by Tuladhar et al. (1997). Previous studies have indicated that $5-\mathrm{HT}_{3}$ receptors in guinea-pig ileum are unlikely to be directly activated by $30 \mathrm{nM} 5$-HT. For example, Lucchelli et al. (1995) found that at least $300 \mathrm{nM} 5-\mathrm{HT}$ is needed to produce minimal activation of $5-\mathrm{HT}_{3}$ receptors on neurons in this tissue. Thus, the concentrations used by Tuladhar et al. would directly excite $5-\mathrm{HT}_{3}$ receptors in a manner analogous to 2 -me-5-HT in the present study, but $30 \mathrm{nM} 5$-HT might only activate the receptors indirectly, for example by releasing mucosal 5-HT. The initial action of luminal 5-HT is probably at a receptor with a much higher affinity for $5-\mathrm{HT}$. The $\mathrm{EC}_{50}$ for $5-\mathrm{HT}_{4}$ receptors in this tissue is $15 \mathrm{nM}$ (Buchheit et al., 1985), which is consistent with these receptors being the targets of low concentrations of 5-HT applied in the lumen. This was demonstrated directly in the present study, since SB 207266 blocked the effects of both 5-HT and RS 67506 . Interestingly, granisetron reversed the facilitation induced by both RS 67506 and 2-me-5-HT, whereas SB 207266 had no effect on the facilitation induced by $2-\mathrm{me}-5-\mathrm{HT}$. That is, $5-\mathrm{HT}_{3}$ receptors are required when $5-\mathrm{HT}_{4}$ receptors facilitate peristalsis, but not the reverse. This implies that the two types of receptor are arranged in series with $5-\mathrm{HT}_{4}$ receptors preceding $5-\mathrm{HT}_{3}$ receptors in the pathway (Figure 5). Both classes of 5-HT receptors are widely expressed within the enteric neural circuitry, but the efficacy of the luminally applied antagonists suggests that the receptors for facilitation of propulsion are in, or close, to the mucosa. Evidence for this conclusion comes from the finding that these antagonists have differing effects on motility when they are applied to the lumen or to the serosa in modified Trendelenberg preparations (Tuladhar et al., 1997; Ellis et al., 2013). The most likely mechanism is that low concentrations of 5-HT in the lumen act via $5-\mathrm{HT}_{4}$ receptors on $\mathrm{EC}$ cells to release enough 5-HT to raise the mucosal concentration to a level capable of exciting $5-\mathrm{HT}_{3}$ receptors (Figure 5). Guinea-pig EC cells are immunoreactive for $5-\mathrm{HT}_{4}$ receptors and activation of these receptors leads to release of 5-HT (Hoffman et al., 2012). The 5- $\mathrm{HT}_{3}$ receptors involved in the facilitation of propulsion by luminal 5-HT are probably those on mucosal nerve terminals of myenteric $\mathrm{AH}$ neurons that have been found to be excited by mucosal application of 5-HT (Bertrand et al., 2000).

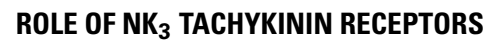

The facilitation of peristalsis induced by 5 -HT, fluoxetine, and 2-me-5-HT was blocked by the specific $\mathrm{NK}_{3}$ tachykinin antagonist, SR 142801. This indicates that the release of a tachykinin, and its subsequent interaction with $\mathrm{NK}_{3}$ receptors, plays a critical role in the facilitatory pathway. $\mathrm{NK}_{3}$ tachykinin receptors are found on many neurons in the guinea-pig enteric nervous system, including myenteric AH neurons (Jenkinson et al., 1999) and are 


\section{A 5 -HT (30 nM)}

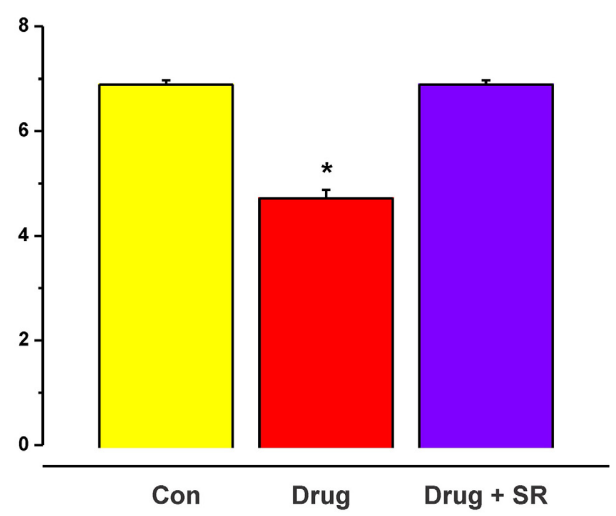

B Fluoxetine (1 nM)

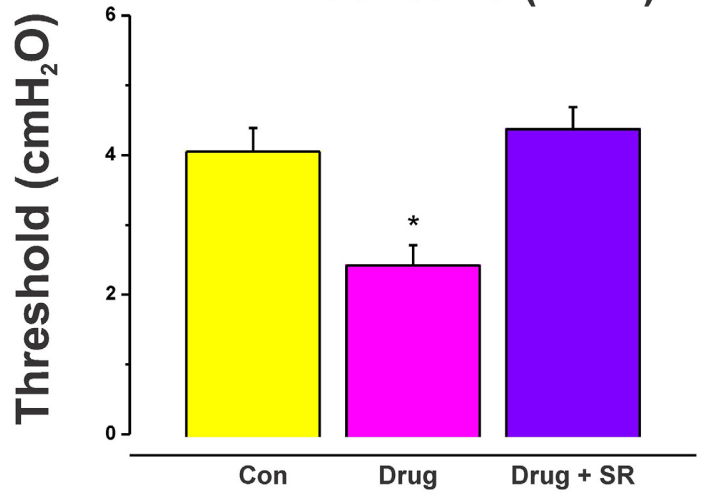

c 2-me-5-HT (1 mM)

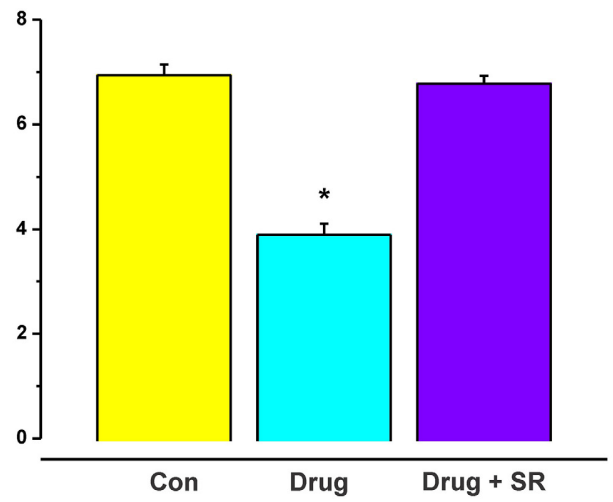

FIGURE 3 | Effects of blockade of $\mathrm{NK}_{3}$ tachykinin receptors on the reduction in threshold for initiation of propulsion evoked by serotonin agonists. The specific $N_{3}$ tachykinin receptor antagonist SR 142801 (SR; $100 \mathrm{nM}$ ) blocked the reduction in threshold for initiation of propulsive contractions in the ileum induced by $5-\mathrm{HT}$ (A), fluoxetine (B), and 2-me-5-HT (C). *Indicates significantly different from control with $P<0.05$ in all cases.

implicated in both ascending and descending reflex pathways in the guinea-pig ileum (Johnson et al., 1996, 1998). However, their role in reflexes in dissected flat sheet preparations is largely confined to responses to mucosal distortion, while reflex responses to distension are unaffected by blockade of these receptors (Johnson
A SB $207266(10 \mathrm{nM})$

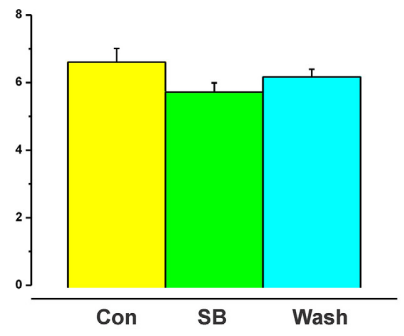

B Granisetron $(1 \mu \mathrm{M})$

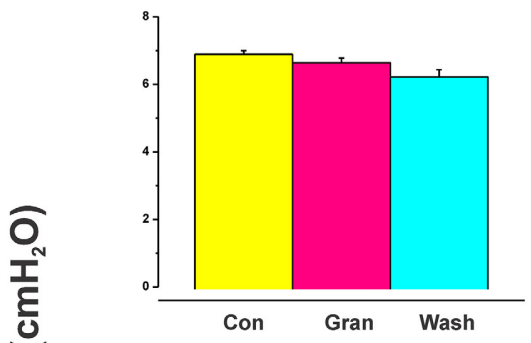

C SB 207266 and Granisetron

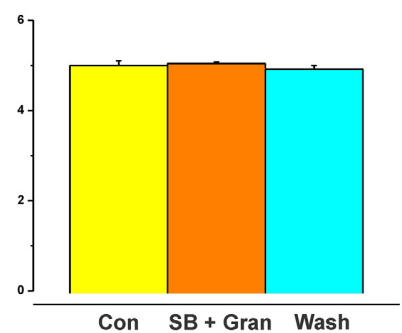

D SR 142801 (100 nM)

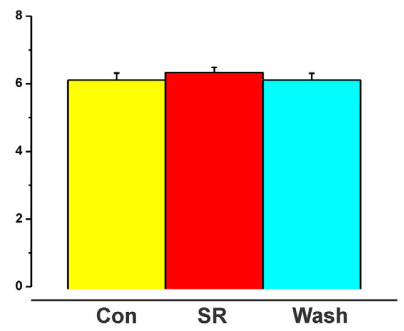

FIGURE 4 | Effects of blockade of $5-\mathrm{HT}_{4}, 5-\mathrm{HT}_{3}$, and $\mathrm{NK}_{3}$ receptors on the threshold for initiation of propulsion in the absence of other drugs. SB 207266 and granisetron when added to the luminal perfusate on their own, or in combination, had no effect on the threshold pressure for initiation of propulsive contractions (A-C). The specific $\mathrm{NK}_{3}$ tackykinin receptor antagonist SR $142801(100 \mathrm{nM})$ also had no effect on the threshold pressure for propulsive contractions (D).

et al., 1998). This suggests that $\mathrm{NK}_{3}$ receptors are involved in the circuitry underlying the facilitation of distension by luminal 5HT, but not in reflex pathways activated by distension. Slow EPSPs mediated by $\mathrm{NK}_{3}$ tachykinin receptors are prominent in myenteric AH neurons (Alex et al., 2001; Johnson and Bornstein, 2004). Furthermore, computer simulations show that slow synaptic transmission within the circumferentially projecting network of 


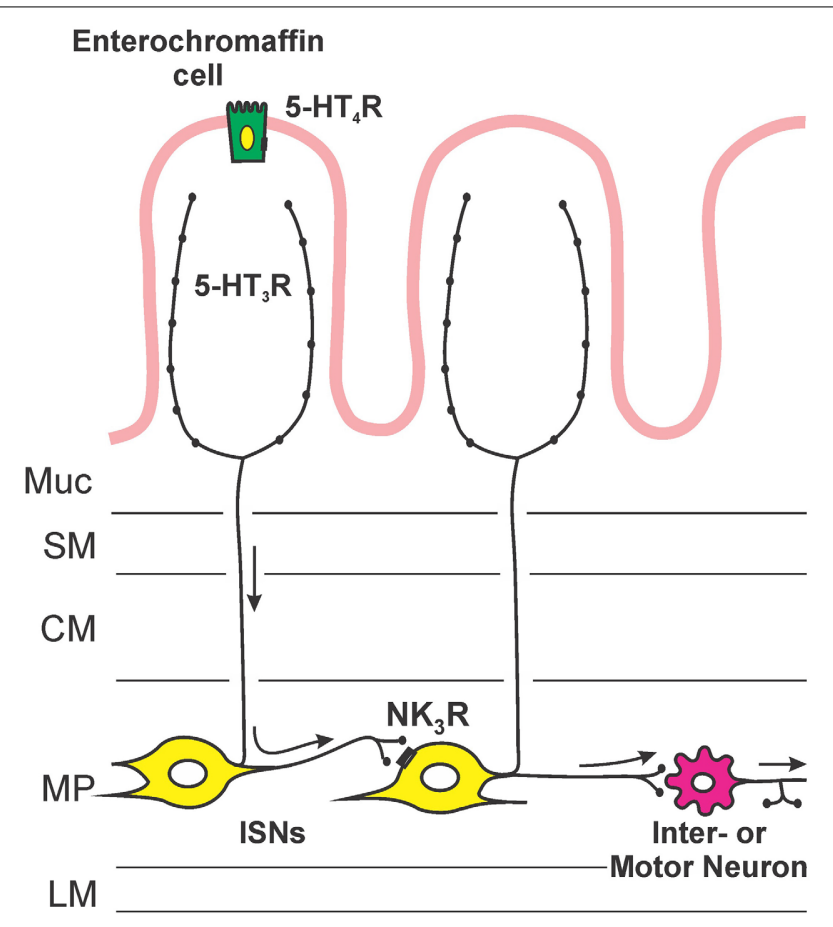

FIGURE 5 | An hypothesis about the sequence of mechanisms by which exogenous or endogenous 5-HT in the lumen enhances propulsion in the guinea-pig ileum. $5-\mathrm{HT}$ acts on $5-\mathrm{HT}_{4}$ receptors on enterochromaffin cells to release more $5-\mathrm{HT}$, this higher concentration of $5-\mathrm{HT}$ then excites mucosal terminals of myenteric $\mathrm{AH}$ neurons via $5-\mathrm{HT}_{3}$ receptors. The myenteric $\mathrm{AH}$ neurons then release tachykinins to enhance the excitability of distension-sensitive myenteric $\mathrm{AH}$ neurons via $\mathrm{NK}_{3}$ receptors.

connections between myenteric AH neurons is important for determining the magnitudes of responses to ongoing physiological stimuli (Thomas et al., 2000, 2004). This raises the possibility that excitation of myenteric AH neurons by luminal 5-HT leads to activation of a recurrent feedback circuit involving slow transmission (via $\mathrm{NK}_{3}$ receptors) between myenteric $\mathrm{AH}$ neurons. This could in turn generate enhanced responsiveness to sensory stimuli such as distension, i.e., facilitation of propulsion.

This leads us to postulate that low concentrations of 5-HT act on $5-\mathrm{HT}_{4}$ receptors on EC cells in the mucosa, releasing 5-HT that then activates $5-\mathrm{HT}_{3}$ receptors on mucosal terminals of myenteric AH neurons. Higher concentrations of 5-HT in the lumen (Tuladhar et al., 1997) or 5- $\mathrm{HT}_{3}$ agonists like 2-me-5-HT act directly on the mucosal nerve endings of myenteric $\mathrm{AH}$ neurons, bypassing the requirement for activation of $5-\mathrm{HT}_{4}$ receptors. The activation of myenteric $\mathrm{AH}$ neurons leads to the release of tachykinins acting at $\mathrm{NK}_{3}$ receptors on other myenteric $\mathrm{AH}$ neurons, thereby enhancing their overall excitability and making them more sensitive to the saline distensions used to excite peristalsis (Figure 4).

\section{MECHANISM OF ACTION OF FLUOXETINE}

The similar sensitivity of responses to $5-\mathrm{HT}_{4}$ antagonists, and the fact that fluoxetine is a specific inhibitor of 5-HT reuptake, suggests that $1 \mathrm{nM}$ fluoxetine acts to increase the extracellular concentration of 5-HT in the intestinal mucosa enough to activate $5-\mathrm{HT}_{4}$ receptors in a similar way to $30 \mathrm{nM} 5-\mathrm{HT}$. This could also account for the enhancement by $1 \mathrm{nM}$ fluoxetine of propulsion of artificial fecal pellets in the guinea-pig distal colon (Wade et al., 1996). However, higher concentrations of fluoxetine (100 and $300 \mathrm{nM}$ ) had no effect on the initiation of propulsive motor patterns, and Wade et al. (1996) found that such concentrations of fluoxetine inhibited colonic transit (a result we have confirmed in an unpublished study). Thus, while low concentrations of fluoxetine facilitate propulsive motor patterns in both ileum and colon, higher concentrations do not.

The concentration dependence may result from the properties of the 5-HT transporter itself. Chen et al. (1998) found that the $K_{\mathrm{i}}$ for fluoxetine on a cloned guinea-pig serotonin transporter was about $48 \mathrm{nM}$. That is, fluoxetine depresses reuptake of 5-HT at concentrations comparable to those that inhibit propulsive motor patterns in the colon and has very little effect at concentrations that facilitate ileal or colonic transit. Thus, increases in extracellular 5-HT produced by low concentrations of fluoxetine may be highly localized, with uninhibited transporters limiting spread of 5-HT beyond the vicinity of the mucosal terminals of enteric neurons. At higher concentrations, transporter capacity might be reduced sufficiently to allow diffusion of 5-HT to more distant sites where it can interact with inhibitory $5-\mathrm{HT}_{1 \mathrm{~A}}$ receptors (Galligan et al., 1988), thereby suppressing the facilitation of peristalsis or even reversing it.

\section{ROLE OF MUCOSAL 5-HT}

There is no doubt that release of mucosal 5-HT plays a major role in the nausea and vomiting produced by ingestion of various toxins (Sanger and Andrews, 2006) and the hypersecretion leading to diarrhea produced by luminal exposure to either the bacterium Vibrio cholera or its exotoxin, cholera toxin (Farthing, 2002; Lundgren, 2002). However, other physiological roles of mucosal 5-HT are significantly less clear. The present data strongly indicate that mucosal 5-HT is not necessary for distension to evoke propulsive motor activity. Both the absence of an effect of luminal $5-\mathrm{HT}_{3}$ or $5-\mathrm{HT}_{4}$ antagonists on their own on the threshold pressure for distension-evoked propulsion and previous results showing that such reflexes can be evoked in the absence of the mucosa (Costa and Furness, 1976; Yokoyama and Ozaki, 1980; Tsuji et al., 1992; Spencer et al., 2011) or mucosal 5-HT (Heredia et al., 2013) support this conclusion. This contrasts with the finding that nutrient-induced segmentation is largely suppressed by $5-\mathrm{HT}_{3}$ or $5-\mathrm{HT}_{4}$ antagonists in the lumen of the small intestine (Ellis et al., 2013). Both physiological data and computer simulations suggest that the initial sensory transduction step in nutrient-induced segmentation is mediated by both cholecystokinin (CCK) and 5-HT, with mucosal 5-HT also playing a role in providing feedback to enter neural motor pattern generators about the overall contractile state of the muscle (Chambers et al., 2011; Ellis et al., 2013). It has recently been demonstrated that a specific subset of enteroendocrine cells contains both CCK and 5-HT, while there are others that contain only one of these mediators (Cho et al., 2014). Thus, the physiological role of mucosal 5-HT may vary according to the stimulus that evokes 
its release. Chemical stimuli, different nutrients, and other food components, might be expected to produce moderate levels of release in various combinations with other mucosal mediators, while contractile activity appears to release $5-\mathrm{HT}$ via mechanical deformation of the mucosa (Bertrand, 2006).

\section{CONCLUSIONS}

This study proposes a way in which 5 -HT facilitates propulsive contractions in the guinea-pig small intestine. Increased availability of 5-HT at low concentrations in the mucosa of the intestine activates high affinity $5-\mathrm{HT}_{4}$ receptors, which triggers the release of more $5-\mathrm{HT}$. This then acts on $5-\mathrm{HT}_{3}$ receptors to excite enteric neural circuits, likely to involve release of tachykinins that facilitate propulsive reflexes.

\section{ACKNOWLEDGMENTS}

This work was supported by SmithKline Beecham, Australia and grants from the National Health and Medical Research Council of Australia $(114103,56642)$.

\section{REFERENCES}

Alex, G., Kunze, W. A., Furness, J. B., and Clerc, N. (2001). Comparison of the effects of neurokinin-3 receptor blockade on two forms of slow synaptic transmission in myenteric AH neurons. Neuroscience 104, 263-269. doi: 10.1016/S0306-4522(01)00064-1

Bertrand, P. P. (2006). Real-time measurement of serotonin release and motility in guinea pig ileum. J. Physiol. 577, 689-704. doi: 10.1113/jphysiol.2006.117804

Bertrand, P. P., and Bornstein, J. C. (2002). ATP as a putative sensory mediator: activation of intrinsic sensory neurons of the myenteric plexus via P2X receptors. J. Neurosci. 22, 4767-4775.

Bertrand, P. P., Kunze, W. A., Bornstein, J. C., Furness, J. B., and Smith, M. L. (1997). Analysis of the responses of myenteric neurons in the small intestine to chemical stimulation of the mucosa. Am. J. Physiol. 273, G422-G435.

Bertrand, P. P., Kunze, W. A., Furness, J. B., and Bornstein, J. C. (2000). The terminals of myenteric intrinsic primary afferent neurons of the guinea-pig ileum are excited by 5-hydroxytryptamine acting at 5-hydroxytryptamine3 receptors. Neuroscience 101, 459-469. doi: 10.1016/S0306-4522(00) 00363-8

Buchheit, K. H., Engel, G., Mutschler, E., and Richardson, B. (1985). Study of the contractile effect of 5-hydroxytryptamine (5-HT) in the isolated longitudinal muscle strip from guinea-pig ileum. Evidence for two distinct release mechanisms. Naunyn Schmiedebergs Arch. Pharmacol. 329, 36-41. doi: 10.1007/BF00695189

Chambers, J. D., Bornstein, J. C., and Thomas, E. A. (2011). Multiple neural oscillators and muscle feedback are required for the intestinal fed state motor program. PLoS ONE 6:e19597. doi: 10.1371/journal.pone.0019597

Chen, J. X., Pan, H., Rothman, T. P., Wade, P. R., and Gershon, M. D. (1998). Guinea pig 5-HT transporter: cloning, expression, distribution, and function in intestinal sensory reception. Am. J. Physiol. 275, G433-G448.

Cho, H. J., Callaghan, B., Bron, R., Bravo, D. M., and Furness, J. B. (2014). Identification of enteroendocrine cells that express TRPA1 channels in the mouse intestine. Cell Tissue Res. 356, 77-82. doi: 10.1007/s00441-013-1780-x

Costa, M., and Furness, J. B. (1976). The peristaltic reflex: an analysis of the nerve pathways and their pharmacology. Naunyn Schmiedebergs Arch. Pharmacol. 294, 47-60. doi: 10.1007/BF00692784

Ellis, M., Chambers, J. D., Gwynne, R. M., and Bornstein, J. C. (2013). Serotonin and cholecystokinin mediate nutrient-induced segmentation in guinea pig small intestine. Am. J. Physiol. Gastrointest. Liver Physiol. 304, G749-G761. doi: 10.1152/ajpgi.00358.2012

Farthing, M. J. (2002). Novel targets for the control of secretory diarrhoea. Gut 50(Suppl. 3), III15-III18. doi: 10.1136/gut.50.suppl_3.iii15

Fung, C., Ellis, M., and Bornstein, J. C. (2010). Luminal cholera toxin alters motility in isolated guinea-pig jejunum via a pathway independent of 5-HT(3) receptors. Front. Neurosci. 4:162. doi: 10.3389/fnins.2010.00162
Galligan, J. J., Surprenant, A., Tonini, M., and North, R. A. (1988). Differential localization of 5-HT1 receptors on myenteric and submucosal neurons. Am. J. Physiol. 255, G603-G611.

Grider, J. R., Kuemmerle, J. F., and Jin, J. G. (1996). 5-HT released by mucosal stimuli initiates peristalsis by activating $5-\mathrm{HT} 4 / 5-\mathrm{HT} 1 \mathrm{p}$ receptors on sensory CGRP neurons. Am. J. Physiol. 270, G778-G782.

Gwynne, R. M., and Bornstein, J. C. (2007). Local inhibitory reflexes excited by mucosal application of nutrient amino acids in guinea pig jejunum. Am. J. Physiol. Gastrointest. Liver Physiol. 292, G1660-G1670. doi: 10.1152/ajpgi.00580.2006

Gwynne, R. M., Thomas, E. A., Goh, S. M., Sjovall, H., and Bornstein, J. C. (2004). Segmentation induced by intraluminal fatty acid in isolated guinea-pig duodenum and jejunum. J. Physiol. 556, 557-569. doi: 10.1113/jphysiol.2003. 057182

Heredia, D. J., Gershon, M. D., Koh, S. D., Corrigan, R. D., Okamoto, T., and Smith, T. K. (2013). Important role of mucosal serotonin in colonic propulsion and peristaltic reflexes: in vitro analyses in mice lacking tryptophan hydroxylase 1. J. Physiol. 591, 5939-5957. doi: 10.1113/jphysiol.2013.2 56230

Hoffman, J. M., Tyler, K., Maceachern, S. J., Balemba, O. B., Johnson, A. C., Brooks, E. M., et al. (2012). Activation of colonic mucosal 5-HT(4) receptors accelerates propulsive motility and inhibits visceral hypersensitivity. Gastroenterology 142 , 844.e4-854.e4. doi: 10.1053/j.gastro.2011.12.041

Jenkinson, K. M., Morgan, J. M., Furness, J. B., and Southwell, B. R. (1999). Neurons bearing NK(3) tachykinin receptors in the guinea-pig ileum revealed by specific binding of fluorescently labelled agonists. Histochem. Cell Biol. 112, 233-246. doi: 10.1007/s004180050411

Jin, J. G., Foxx-Orenstein, A. E., and Grider, J. R. (1999). Propulsion in guinea pig colon induced by 5 -hydroxytryptamine $(\mathrm{HT})$ via $5-\mathrm{HT}_{4}$ and $5-\mathrm{HT}_{3}$ receptors. J. Pharmacol. Exp. Ther. 288, 93-97.

Johnson, P. J., and Bornstein, J. C. (2004). Neurokinin-1 and -3 receptor blockade inhibits slow excitatory synaptic transmission in myenteric neurons and reveals slow inhibitory input. Neuroscience 126, 137-147. doi: 10.1016/j.neuroscience.2004.03.021

Johnson, P. J., Bornstein, J. C., and Burcher, E. (1998). Roles of neuronal $\mathrm{NK}_{1}$ and $\mathrm{NK}_{3}$ receptors in synaptic transmission during motility reflexes in the guinea-pig ileum. Br. J. Pharmacol. 124, 1375-1384. doi: 10.1038/sj.bjp.07 01967

Johnson, P. J., Bornstein, J. C., Yuan, S. Y., and Furness, J. B. (1996). Analysis of contributions of acetylcholine and tachykinins to neuro-neuronal transmission in motility reflexes in the guinea-pig ileum. Br. J. Pharmacol. 118, 973-983. doi: 10.1111/j.1476-5381.1996.tb15495.x

Keating, D. J., and Spencer, N. J. (2010). Release of 5-hydroxytryptamine from the mucosa is not required for the generation or propagation of colonic migrating motor complexes. Gastroenterology 138, 659-670; 670.e1-670.e2. doi: 10.1053/j.gastro.2009.09.020

Li, Z., Chalazonitis, A., Huang, Y. Y., Mann, J. J., Margolis, K. G., Yang, Q. M., et al. (2011). Essential roles of enteric neuronal serotonin in gastrointestinal motility and the development/survival of enteric dopaminergic neurons. J. Neurosci. 31, 8998-9009. doi: 10.1523/JNEUROSCI.6684-10.2011

Lucchelli, A., Santagostino-Barbone, M. G., Barbieri, A., Candura, S. M., and Tonini, M. (1995). The interaction of antidepressant drugs with central and peripheral (enteric) $5-\mathrm{HT}_{3}$ and $5-\mathrm{HT}_{4}$ receptors. Br. J. Pharmacol. 114, 1017-1025. doi: 10.1111/j.1476-5381.1995.tb13307.x

Lundgren, O. (2002). Enteric nerves and diarrhoea. Pharmacol. Toxicol. 90, 109-120. doi: 10.1034/j.1600-0773.2002.900301.x

Sanger, G. J., and Andrews, P. L. (2006). Treatment of nausea and vomiting: gaps in our knowledge. Auton. Neurosci. 129, 3-16. doi: 10.1016/j.autneu.2006. 07.009

Spencer, N. J., Nicholas, S. J., Robinson, L., Kyloh, M., Flack, N., Brookes, S. J., et al. (2011). Mechanisms underlying distension-evoked peristalsis in guinea pig distal colon: is there a role for enterochromaffin cells? Am. J. Physiol. Gastrointest. Liver Physiol. 301, G519-G527. doi: 10.1152/ajpgi.00101.2011

Thomas, E. A., Bertrand, P. P., and Bornstein, J. C. (2000). A computer simulation of recurrent, excitatory networks of sensory neurons of the gut in guinea-pig. Neurosci. Lett. 287, 137-140. doi: 10.1016/S0304-3940(00) 01182-4

Thomas, E. A., Sjovall, H., and Bornstein, J. C. (2004). Computational model of the migrating motor complex of the small intestine. Am. J. 
Physiol. Gastrointest. Liver Physiol. 286, G564-G572. doi: 10.1152/ajpgi.003 69.2003

Tsuji, S., Anglade, P., Ozaki, T., Sazi, T., and Yokoyama, S. (1992). Peristaltic movement evoked in intestinal tube devoid of mucosa and submucosa. Jpn. J. Physiol. 42, 363-375. doi: 10.2170/jjphysiol.42.363

Tuladhar, B. R., Kaisar, M., and Naylor, R. J. (1997). Evidence for a 5-HT 3 receptor involvement in the facilitation of peristalsis on mucosal application of 5-HT in the guinea pig isolated ileum. Br. J. Pharmacol. 122, 1174-1178. doi: 10.1038/sj.bjp.0701503

Wade, P. R., Chen, J., Jaffe, B., Kassem, I. S., Blakely, R. D., and Gershon, M. D. (1996). Localization and function of a 5-HT transporter in crypt epithelia of the gastrointestinal tract. J. Neurosci. 16, 2352-2364.

Wardle, K. A., Bingham, S., Ellis, E. S., Gaster, L. M., Rushant, B., Smith, M. I., et al. (1996). Selective and functional 5-hydroxytryptamine4 receptor antagonism by SB 207266. Br. J. Pharmacol. 118, 665-670. doi: 10.1111/j.14765381.1996.tb15452.x

Yokoyama, S., and Ozaki, T. (1980). Effects of gut distension on Auerbach's plexus and intestinal muscle. Jpn. J. Physiol. 30, 143-160. doi: 10.2170/jjphysiol.30.143
Conflict of Interest Statement: The authors declare that the research was conducted in the absence of any commercial or financial relationships that could be construed as a potential conflict of interest.

Received: 02 July 2014; paper pending published: 01 August 2014; accepted: 03 September 2014; published online: 19 September 2014.

Citation: Gwynne RM, Clarke AJ, Furness JB and Bornstein JC (2014) Both exogenous 5-HT and endogenous 5-HT, released by fluoxetine, enhance distension evoked propulsion in guinea-pig ileum in vitro. Front. Neurosci. 8:301. doi: 10.3389/fnins. 2014.00301

This article was submitted to Autonomic Neuroscience, a section of the journal Frontiers in Neuroscience.

Copyright $\odot 2014$ Gwynne, Clarke, Furness and Bornstein. This is an open-access article distributed under the terms of the Creative Commons Attribution License (CC BY). The use, distribution or reproduction in other forums is permitted, provided the original author(s) or licensor are credited and that the original publication in this journal is cited, in accordance with accepted academic practice. No use, distribution or reproduction is permitted which does not comply with these terms. 